\title{
Dynamics of Friendship in Selected Novels of Chinua Achebe and Isdore Okpewho
}

\author{
Ndubuisi H. Onyemelukwe ${ }^{1}$, Catherine O. Ogbechie ${ }^{1} \&$ Winniefred E. Ibeana ${ }^{1}$ \\ ${ }^{1}$ Department of Languages, School of Liberal Studies, Yaba College of Technology, Yaba-Lagos, Nigeria. \\ Correspondence: Ndubuisi H. Onyemelukwe, Department of Languages, School of Liberal Studies, Yaba \\ College of Technology, Yaba-Lagos, Nigeria. Tel.:234-803-574-442. E-mail: hyginusndubuisi@yahoo.com
}

Received: January 30, 2014 Accepted: May 15, 2014 Online Published: July 30, 2014

doi: 10.5539/ijel.v4n4p107 URL: http://dx.doi.org/10.5539/ijel.v4n4p107

\begin{abstract}
This study is prompted by the urge to enhance the quality of friendship in life. The urge to enhance the quality of friendship in life emanates from the rampant abuse of the indispensable relationship. The focus of the study on friendship aims at highlighting positive friendship attitudes just as it targets to criticise and proscribe negative ones. This bipolar objective of the study is pursued for the purpose of conceptualising ideal friendship dynamics, and concurrently, improve the quality of friendship among people. Consequently, three novels each of Chinua Achebe (Achebe) and Isdore Okpewho (Okpewho) are x-rayed in the study to identify, explain and evaluate identified variants of friendship in them. From the stable of Achebe the following novels are purposively selected for the study: Things Fall Apart (TFA), Anthills of the Savannah (Anthills) and No Longer at Ease (NLAE), while from the canon of Okpewho these are selected: Tides, Call Me by My Rightful Name (CMBMRN) and The Victims (Thevics). The named novels are selected, because they are perceived to have unfolded such patterns of friendship which very much reciprocate real life friendships. Relying on the theoretical premise which explicates friendship as a sharing of love, the study has, by means of an analytical discussion of the friendship dynamics unfolded in the reference novels, shown that friendship in quasi broad taxonomical terms is either false or true. True friendship, noted in the study to be selfless and intimate, following Baconian notion of the concept, is friendship par excellence and as such anchors on St. Paul's notion of altruistic love by which it is conceptualised as a sharing of love between friends who could be homogeneous or heterogeneous, depending on their sex distribution which tallies or varies respectively. The practical implications of the foregoing major findings are that friendship, to be perpetual, thrives on mutual desirables, especially mutual counselling, chastisement, apology and forgiveness as situations may prompt and abominates betrayal, insincerity, dishonesty and redundancy. The pragmatic import of the major findings of the study is that humanity cannot do without sharing altruistic love as conceptualised by St. Paul in $1^{\text {st }}$ Corinthians. 13: 4-13 which translates to universal friendship: love-anchored relationship in every sphere of life.
\end{abstract}

Keywords: friendship, dynamics, altruistic love, universal friendship, homogeneous, heterogeneous

\section{Introduction}

Basically conceptualised, friendship refers to a relationship between friends. This relationship operates in variant dimensions as indexed in the polysemous semantics of "friend" as a lexical item in English lexicon. Taking definitional clues from the international students' edition of Oxford Advanced Learners' Dictionary (p. 600), a friend means any of the following:

(a) a non-family member but a beloved acquaintance.

(b) a philanthropist who offers regular financial support to a charity organisation.

(c) an ideational or ideological collaborator.

(d) a mutual reference term for parliamentarians and legal practitioners.

(e) a Society of Friends member.

(f) a euphemistic metaphor for an offensive ideational or ideological opponent.

In pure pragmatic terms, a friend refers to (a) and (c) both of which are subsumed in (b) within an institutional context. Observe that (c) is not exclusive to (a) as to other foregoing definitions except (f) which is an ironical definition of the term, and therefore, antonymous to (a)-(e). Hence, for any two or more people, including siblings and other relatives, to be regarded as friends, each must be (c) to the others, meaning that they 
substantially share certain interests and opinions. It is in this sense that some relatives, close or distant, are seen not to be friends and vice versa.

In the light of the expository insights of the paragraph immediately before this (a) and (c) underpin our working notion of friendship in this study. Consequently, friendship is defined in the study as a relationship between two or more acquaintances (friends) anchored on the principles of love and mutual regard for one another's interests and opinions. Nothing in this definition states that friends do not differ on some issues. Experiences in life show that friends can differ on some issues, but agree on most. Moreover, when they differ, they make determined effort to find a compromise position the failure of which mars their friendship, being indicative of a mismanaged conflict.

That friends are not always in agreement, coupled with the fact that some friendships last longer than others with some being very short-lived, points to the differing wavelengths of friendship. The changing patterns of friendship translate to the dynamics of friendship which is mirrored in the conventional classification of friendship before now. The conventional classification recognises the following as types of friendship: casual, fair-weather, occasional and intimate friendship. Against this backdrop, three novels each of Chinua Achebe (Achebe) and Isdore Okpewho (Okpewho) are x-rayed in the study to identify, explain and evaluate the foregoing variants of friendship. From the stable of Achebe the following novels are purposively selected for the study: Things Fall Apart (TFA), Anthills of the Savannah (Anthills) and No Longer at Ease (NLAE), while from the canon of Okpewho these are selected: Tides, Call Me by My Rightful Name (CMBMRN) and The Victims (Thevics). The named novels are selected, because they are perceived to have unfolded such patterns of friendship which very much reciprocate real life friendships.

The focus of the study on friendship aims at highlighting positive friendship attitudes just as it targets to criticise and proscribe negative ones. This bipolar objective of the study is pursued for the purpose of conceptualising ideal friendship dynamics, and consequently, improve the quality of friendship among people.

\section{Theoretical Framework: Friendship as a Sharing of Love}

The purpose of this section is to explicate friendship as a platform for sharing love. To effectively achieve this purpose it is essential to conceptualise love. As an English word love is in everyday use, but too highly abused. That it is too highly abused means that it is grossly misunderstood, generally. It is beyond the scope of this study to state, examine, contextualise and reject the virtually countless misconceptions about love, especially when it is amourous. Amourous love is so abused that, in line with Francis Bacon's postulation, it is impossible to love and be wise.

Love, in proper perspective, is basically an emotion or a spiritual force which objectifies all-inclusive positive goals. In other words, there is nothing negative about love. See Hill (1983) and Mbukanma (2007, 2010). St. Paul, a notable Christian personality and a Divinely ordained evangelist of Gentile nations, is credited with an infallible treatise on love in $1^{\text {st }}$ Corinthians 13:4-13 which corroborates the foregoing basic paradigmatic conceptualisation of love:

Love is patient, kind and devoid of envy. It is not boastful or arrogant. It is not ill-mannered and seeks not its own interest. Love overcomes anger and forgets offences. It does not take delight in wrong-doing, but rejoices in truths. Love excuses everything, believes all things, hopes all things and endures all thingsLove has no end and ...is the greatest of all positive emotions such as faith andhope.

Let it promptly be explained that all things in the context of St. Paul's treatise refer to Divine revelations. It does not mean every utterance made by one's beloved, true or false, and should not, since the treatise categorically asserts that love celebrates the truth, meaning that it abominates falsehood, insincerity or dishonesty. Another cardinal attribute of love explicit in the treatise is that love is selfless. That is, love seeks the interest of others. Nothing about the altruistic nature of love, howbeit, ratifies self-hatred. St. Paul's notion of altruistic love is, therefore, synonymous with in-exclusive self-love. In-exclusive self-love refers to love that begins with self but does not end with self but rather radiates to others as much as it cares for self, hence, the golden rule according to St. Paul's Master and Saviour: Do to others what you want others to do to you.

Altruistic love as conceptualised in the paragraphs before this is the character of friendship as understood in this study. For avoidance of doubt, friendship in the context of the study refers to the relationship between friends as defined in (a) and (c) of the introductory section. Such friendship incorporates the following inter-relationship indices: cordiality or fondness, regular or irregular companionship, tolerance, sharing of ideas and secrets, perpetuity and offering a helping hand as may be necessitated. The foregoing insights explain the ratification of platonic courtship before marriage in Christianity which embeds the message that the holy matrimony is an 
offshoot of heterogeneous friendship, and so, an improved form of it, such that a happy perpetual marriage must first commence as friendship as already expounded and as subsequently typified in pure technical terms. The insights further evince friendship to be a sharing of love: selfless love, whether it is heterogeneous or homogeneous in terms of gender distribution of the friends concerned. The notion of altruistic love in this paragraph mirrors Francis Bacon's reflection on love: Nuptial love makes mankind; friendly love perfects it, but wanton love corrupts it. See the referee's essay on "Of Love" at http://www.authorama.com/essays-of-francis-bacon-27.html. It must be noted here that tolerance as an attribute of friendship does not translate to aiding and abetting. It rather means granting a friend personal liberties that are neither immoral nor illegal. So it is sharply opposed to aiding and abetting which condones every shed of immorality and illegality. In other words, once friendship incubates aiding and abetting, it loses recognition as such, having metamorphosed into "gansterism" or "cultism."

The conceptual import of the last paragraph before this is that this study recognises as authentic friendship only the last of the conventional type of friendship listed in the introduction, namely, intimate friendship. Consequently, for the purpose of the study, intimate friendship translates to altruistic friendship which as a rule anchors on St. Paul's notion of altruistic love. Hence, for any two or more people to be regarded as friends, their inter-relationship must reflect the foregoing indices which directly stem from the dictates of altruistic love. Altruistic friendship is solely recognised in the study, because it solely yields true friends, i.e., friends in need who are friends indeed, also conventionally recognised as the ideal friends. In the final analysis, we submit that friendship must be ideal to be friendship, else it becomes mere acquaintance. The friendship between Biblical David and Jonathan (1 Sam. 18:1-4...) quickly comes to mind here as a perfect example as well as that between Jesus and Lazarus (Jn. 11:1-44). It, therefore, follows that other conventional types of friendship, as already identified, are false friendships.

The paragraph before this corroborates Bacon's notion of an ideal friend:

...the best preservative to keep the mind in health is the faithful admonition of a friend Faithful counsel comes only from a perfect and entire friend. Where true friendship obtains, all offices of life are as it were granted to him and his deputy. A friend speaks as the case requires and never on sentiments to unduly please. Where a man cannot fitly play his own part, if he has no friend, he may quit the stage.

As will subsequently be analytically shown, friendship is a necessity as implied in Bacon's notion above. Nevertheless, it must also be cautioned here that it is better to do without friends than to surround oneself with false friends, because false friends can send one to an early grave as human experience has severally demonstrated and as mirrored in Shakespeare's Julius Caesar. In the classical drama, Julius Caesar, the protagonist and king of the Roman Empire, paid the supreme price for strictly no offence. He was rather sent to the grave too early in his royal life by the misplaced ambition of a group of conspirators prominent among whom was Decismus Brutus, his 'best friend' who gave him the final stab as he ran to him for defence. Cf. Bacon's essay on 'Of Friendship' at http://www.authorama.com/essays-of-francis-bacon-27.html. Caesar's pathetic experience demonstrates, most aptly, the platitude incorporated in the maxim which urges people to have a thousand acquaintances, but keep one or two friends, only. In other words, true friends are scarce. Hence, Bacon asserts that it is a mere and miserable solitude to want (lack) true friends without whom the world is but a wilderness. Caesar's experience further demonstrates a cardinal philosophical professional maxim in Guidance and Counselling by which everybody is urged to be his/her own best friends. Consequently, one's choice of friends is an onerous task which demands the highest exercise of precautions and cautions.

In the light of this theoretical framework, the friendships unfolded in the reference novels for this study are $\mathrm{x}$-rayed to be accepted or rejected as such with appropriate justifications, the objective being to enhance authentic and lasting friendship which hardly obtains nowadays. The target objective of the study is necessary, because while some identifiable friendships can boast of being authentic, very few if any can boast of perpetuity (lasting for life).

\section{Analytical Discussion of Identified Patterns of Friendship in the Reference Novels}

The purpose of this section is strictly as stated in the last paragraph of the theoretical framework above. As asserted in the introductory section the patterns of friendship in the reference novels are sufficiently realistic for the analytical attention focussed on them here. For the purpose of reliable findings, the analytical interest of the study is limited to friendship between adults. Attention is exclusively on such friendships, because they exhibit zero tolerance for interference quite unlike friendship between children which generally suffers largely inhibitive parental interferences as profusely mirrored in the friendship between Ubaka and Bomboy in Okpewho's Thevic. Each identified friendship pattern is first captured intra-textually in summary before being typified and evaluated 
in line with the parameters expounded in the theoretical section.

In $T F A$, the friendship between Okonkwo, the protagonist and Obierika cannot pass unnoticed. Both of them are bosom friends indeed as evident in several interactions between them. They exchange visits, regularly just as they host each other at family occasions such as marriage ceremonies. Moreover, they go to places together or schedule to meet at community events like traditional wrestling competitions usually organised to celebrate the new yam festival. Furthermore, wherever and whenever they meet they talk heart to heart. Their friendship is so much an intimate one that Obierika is very much there for Okonkwo when it matters most, irrespective of Okonkwo's frequent deaf ears to his wisdom counsels. Hence, the latter's self-imposed exile on account of 'female murder' together with the pre-departure tribulations following it becomes a very light cross for him, a million thanks to the former's superb home care and regular visits to him at Mbanta. Even when, eventually, Okonkwo hangs himself to escape the white man's justice for senselessly killing an unwelcome human harbinger, he still enjoys Obierika's worthy friendship. Obierika does not only mourn Okonkwo, but also courageously indicts the colonial administration in Umuofia personified by the district commissioner. His indictment of the white man concurrently serves to pay final tribute to his irate friend: "That man was one of the greatest men in Umuofia. You drove him to kill himself and now he will be buried like a dog" (p. 147)

The foregoing scenario depicts a homogenous friendship, the friends in view being only men. The scenario also clearly shows a seeming friendship par excellence between Okonkwo and Obierika, i.e., a seeming authentic friendship, especially for its quality of perpetuity. Nevertheless, it must be pointed out that the friendship anchored much more on Obierika's personality than that of Okonkwo, being an intellectually unbalanced friendship. Indeed, Obierika is more of a benefactor than a friend to Okonkwo. This assertion is valid, because throughout the crisis period of their life, Obierika was always at the giving end. This is the situation, because between the two Obierika is the one blessed with 'uche ndu' (wisdom for life). Consequently, he is also more identifiable as Okonkwo's mentor than his friend. So in TFA, he keeps offering wisdom counsel to Okonkwo even as Okonkwo keeps neglecting him, albeit to his fatal detriment. For instance, he strongly advises Okonkwo never to have a hand in the killing of Ikemefuna not just because the ill-fated lad calls him 'father,' but also because the oracle which decrees the killing of the boy never specified Okonkwo to be the the killer. Obierika's sound logic, notwithstanding, Okonkwo ends up as the person who finally slaughtered Ikemefuna, an innocent boy, even as the boy ran to him for safety. Ikemefuna's innocence is a factor, because an authentic spiritual deconstruction of TFA does not fail to identify the senseless killing as the root of Okonkwo's travails in the world of TFA which explains why he died in the manner already described and buried like a dog as great as he was as one of the lords of the clan.

In the light of the foregoing commentary on Okonkwo/Obierika friendship, every reader of TFA must not fail to learn how to recognise and utilise a wise piece of advice from a friend once it is offered, since the friendship of the duo in question has very clearly shown that it translates to imminent self-destruction to turn deaf ears to wisdom counsel. Another essential lesson about friendship arising from the duo is that a friend should not just be advising another as may be necessitated, but must also strategise to ensure compliance, once it becomes clear that some previous ones have been neglected with dire consequences. Obierika failed in this regard, and so could not save his bosom friend the shame of dying like a dog. His failure in this regard evinces that he maintained his friendship with Okonkwo, accepting him as he was: a foolhardy man of valour with no affective temperament. Not surprisingly, howbeit, the shock he suffers in Okonkwo makes nonsense of the foregoing relationship principle, even as it remains wantonly popular. Consequently, friends should do their best to change each other for good. Acting to change a friend for good is imperative, because accepting him as he is if his personality traits are simply bizarre like those of Okonkwo, tending towards criminality, amorality or moral recklessness, translates to aiding and abetting which renders friendship false.

In Anthills there are interesting patterns of friendship all of which cannot be discussed in this study due to spatial constraints. Consequently, our analytical discussion is restricted to the two most topical friendship dynamics in the novel, namely, the friendship between Sam, His Excellency (HE or Sam, henceforth) and some top civil servants in his dictatorial military administration and the triangular friendship of the civil servants themselves. The civil servants who are also his former classmates or school mates are Ikem Oshodi (Ikem), Christopher Oriko (Chris) and the enigmatic Beatrice (BB).

The trio of Ikem, Chris and BB are part of the civil service of Sam's military regime strictly on account of their school time friendship with HE. As they join the administration, they hope to take their friendship with Sam to a higher level as evident in several disparate and joint friendly discussions between them before the friendship meets its waterloo. Unfortunately, however, this hope is shattered almost as soon as they have joined the civil service of Kangan, no thanks to the ingrate, professor Okong, a political opportunist who selfishly but tactfully 
clashes HE, Ikem and Chris and by extension BB, Chris' fiancée in a cold political power tussle with the duo. Okong crafts his political intrigue such that Ikem and Chris are declared security risks, officially in quick succession beginning with the former. In consequence of the grossly mistaken declaration, Ikem and Chris soon become victims of job loss and subsequently pay the supreme price, extra-officially though.

Ikem, Chris and BB are into a perpetual triangular friendship with BB serving as the connecting rod between Ikem and Chris. BB has to play a mediating role between the duo, because both of them have reformatory socio-political ideological differences. Their self-assigned mission of socio-political reformation is prompted by HE's despotic regime, an offensive surprise to them and BB, especially in view of Sam's school time profile as a cool-headed gentle man. While Ikem favours and executes the prompt radical intellectual approach to socio-political reformation by means of public lectures and mind-throbbing editorials in the National Gazette, Chris counters him with a tactful gradual approach as BB continually strikes a balance between the two. Together three of them consider Sam hooked in the midst of socio-political power jobbers and brokers and in good faith mounts a rescue mission for him and for Kangan polity. Their rescue mission hits the rock, howbeit, as their real enemies in government led by Okong pitch them against HE, mercilessly, destroying them after scandalising HE to sack his government in a mystery palace coup which renders him a guest to unidentified abductors.

Chris and BB put in everything humanly possible to bring to book, the heartless killers of Ikem who first battered and abducted him for illegal detention, but their effort proves futile as Chris himself becomes government enemy no.1 and moves into self-exile to the North, many thanks to BB's co-operation with some other friends like Abdul. Before Chris' most unanticipated heart-rending death in the hand of a trigger-happy police man shortly after the coup, BB holds forth for him and Ikem as a most trust-worthy friend. For Ikem, she mid-wives a posthumous daughter, Amaechina, whose mother is Elewa, Ikem's wife-to-be up to the point of hosting her naming ceremony, while for Chris, she keeps hope alive passionately anticipating the tying of nuptial nuts between both of them.

Both patterns of friendship presented above are heterogeneous, but while the first (that of HE and the trio) is a false friendship, the other is a perfect altruistic friendship, i.e., friendship par excellence. The first is false, because Sam as HE allowed a fifth party to mess up the time-honoured friendship in his insatiable search for political relevance in Kangan targeted at perpetuating himself in absolute power. That is, inordinate political ambition manifesting as sit-tight syndrome is responsible for the false quadrangular friendship, thus, demonstrating the validity of Aristotelian notion about the nature of absolute political power, namely, that it corrupts absolutely. The second is not only a true friendship, but also an intellectually balanced one quite unlike that of Okonkwo and Obierika, each making a significant contribution at various times to preserve the friendship of the other two and that of the three, going by the details of their interactions in the world of Anthills. By and large the two patterns of friendship, taken together, show clearly that unless an unfortunate interference occurs, such as the one from Okong capitalised on Sam's self-destructive ambition, school time friendship blossoms to higher and higher level of intimate networked inter-relationship among the friends involved. Simply put, (political) ambition, if not checkmated, mars friendship.

NLAE, like Anthills, unravels several patterns of friendship all of which cannot be analysed in this study for the same reason of spatial limitation. The analytical interest of the study here is limited to the two most topical of the friendships: the one between Obi Okonkwo (Obi) and Clara and between Obi's mother, Hannah Okonkwo and Mary.

Obi and Clara are engaged to each other. In other words they intend to uplift their friendship to a higher level of heterogeneous intimacy: the holy matrimony. Their noble desire, however, remains a mirage on account of a dogmatic socio-cultural belief and practice, namely, the osu caste system. By this system, the indigenes of a traditional home land are sorted into freeborn and outcasts with highly restricted interactional platform which excludes marriage. Hence, Obi and Clara's proposed marriage cannot be consummated, because Obi is a freeborn while Clara is an outcast. By the proposed marriage, Obi seeks to initiate a socio-cultural revolution under the umbrella of christianity. Nevertheless, the stiff opposition from his parents, Isaac and Hannah Okonkwo as well as his childhood friend, Joseph dovetails the targeted revolution to a failed rebellion, Obi being just a nominal christian.

Hannah Okonkwo and Mary are very close friends. Their friendship is disclosed during Obi's send off party to England at the instance of Rev. Samuel Ikedi of St. Mark's Anglican Church, Umuofia. The party was a religious one put together by Obi's parents strictly for the purpose of committing Obi into God's hand as he leaves Umuofia to temporarily live in England. The opening prayer volunteered by Mary at the occasion says it all 
about her friendship with Obi's mother for out of the abundance of the heart the mouth speaks. See Onyemelukwe and Fatuase (2012) for the powerful opening prayer or p. 8 of the novel.

Obi and Clara's friendship is a true one sacrificed on the altar of identity crisis expressed as nominal Christianity. Identity crisis is the issue at stake, because Obi, by virtue of his formal education at graduate level in England, becomes a half-cast, i.e., partly African and partly European. He is certainly not an authentic Christian going by every disclosure in NLAE about him. His appeal to Christianity is obviously for the selfish purpose of consummating his proposed marriage with Clara. His parents are also victims of identity crisis, largely due to their illiteracy which accounts for their too limited insights about Christian ideals, especially in matrimonial terms. Consequently, they navigate between Christian and pagan identities, and so, find no meeting point, whatsoever, with Obi, their son who is genuinely in love with Clara. The failed friendship between Obi and Clara teaches a cardinal lesson about heterogeneous friendship, generally, stipulating that before youngsters go into such a relationship they must ensure compatibility in every shed of it: educationally, socio-culturally, religiously, socio-economically and more. This indispensable lesson serves to save potential love birds from heart break such as suffered by Obi and Clara, the latter particularly. See Ludlow (1982) for more insights on compatibility.

The friendship between Obi's mother and Mary is very much a homogenous true one, especially for its religious affinity which accounts for the unparalleled goodwill of the latter for the former and her son as articulated in the opening prayer. Moreover, given the extensive age disparity between the two friends which reveals Mary to be virtually young enough to be Hannah's daughter, their enviable relationship teaches that true friendship is possible between an old and a young adult. In other words, age is no barrier to friendship, a homogenous one particularly. It must, however, be pointed out that based on experience such a friendship is uncommon, meaning that friendship is better among peers or approximate peers, especially if it is heterogeneous. This assertion connects the popular maxim which states that there is no true friendship except among equals, age being a fundamental determinant of equality as the key to various status symbols.

In Tides, the friendship between Piriye Dukumo (Dukumo) and Tonwe Brisibe (Tonwe) is pervasive in the world of the epistolary novel. Theirs is a friendship founded on professional affinity, both of them being journalists in the emploi of the National Chronicle, Lagos. In this regard, the latter is the former's benefactor. This fact justifies their closeness as professional colleagues, coupled with their ethno-linguistic homogeneity, the two of them being Beniotu's. Their friendship is so tight that even when their job is sacrificed in the shrine of ethnic cleansing they still maintain a communication continuum by correspondence which remains unbroken for long. Indeed if not for the risky enterprise they embark on at the instance of Dukumo, a younger radical journalist than Tonwe, their friendship would have suffered no interference. The interference, notwithstanding, their friendship remains intact even as they are suddenly rendered incommunicado for as long as only subsequent developments can tell. The interference suffered by their friendship is due to their professional resolve to redress government's oppressive exploitation of crude oil deposits in Beniotu communities, which consequently attracts the attention of the police to them. Their resolve is in pursuance of ethnic nationalism as well as socio-economic emancipation for their people: the Beniotu's.

Dukumo/Tonwe friendship is certainly an altruistic homogeneous one with crucial patriotic undertones from the Beniotu perspective. A note-worthy lesson arising from the friendship is that outside the precincts of native homes, ethno-linguistic homogeneity is a very fertile soil on which friendship grows to possibly blossom into ethnic nationalism and socio-economic emancipation. Ethno-linguistic homogeneity fertilises friendship, while professional affinity catalyses it. Professional affinity as a catalyst for friendship explains Dukumo's heterogeneous friendship with Lati, his prospective new bride with whom he shares no ethnic affinity. It must be pointed out though that Dukumo's prospect of wedding Lati at the expense of his initial matrimony with Tonye is also strongly rooted in childlessness, since the prospect is given expression by Lati's pregnancy for him. Between Dukumo and either of Lati and Tonye, however, attitude beyond childlessness or ethnic affinity counts most in view of his several vociferations to Tonwe on his distinct relationships with both women. The vociferations express Tonye's crass attitude to Dukumo, despite the matrimonial tie between them. Attitude is therefore a serious determinant of the fate of heterogeneous friendship much more than it is for a homogeneous one. This deduction is valid for the fact that Dukumo and Tonye hail from Beniotu ethnic group, but their marriage still hits the rock when without prior warning to the former, the latter walks out of the marriage.

In $C M B M R N$, there is no serious friendship. Absence of serious friendship in the novel is not a surprise, because it is preoccupied with identity issues. Consequently, it features only the petty friendship between Otis, the hero of the novel and Norma, his girlfriend. Their friendship is petty, because nothing about it in the novel indicates any serious commitment from either to the other. The only visible attribute of their friendship is companionship nurtured by extravagance. So Norma follows Otis about to restaurants and disco parties. Norma even feels 
embarrassed by Otis' initially mysterious psychiatric illness, and so, taped his unintelligible utterances during his unconscious moments and showed his parents. Otis' parents commenced immediate corrective actions with Norma no longer on the scene. Her absence from the scene becomes conspicuous when it matters most: journeying to Nigeria from the United States of America for the solution to Otis's intermittent mental case as professionally prescribed. Otis embarks on the journey to and fro alone with his father and Dr. Fishbein.

Otis and Norma's friendship clearly demonstrates the properties of petty friendship conventionally known as fair-weather friendship. An obvious attribute of it is that it is short-lived. Another one is that it thrives on hedonism: an obsession for pleasure. When it is heterogeneous as between Otis and Norma its hedonistic propensity manifests chiefly as irresponsible sexual relationship with any or more of these consequences: contraception, unwanted pregnancy, abortion which could lead to the malfunctioning of the reproductive system and even loss of womb. In the light of the foregoing, petty friendship is a shed of false friendship, especially as it lacks the attribute of perpetuity lasting only as long as good times come the way of the friends involved. In a group of petty (fair-weather) friends one is usually the benefactor, while the rest are beneficiaries, the parasites in metaphorical terms and once the benefactor goes bankrupt, the parasites disappear. It may also be that each of a group of false friends is rich. In that case the one unlucky enough to revert to poverty due to a catastrophic misfortune falls out of grace in the group. Hence, this popular slogan 'no money, no friend' fills the air to warn the rich against surrounding themselves with false friends who are masked enemies.

Like CMBMRN, Thevics unfolds friendship of the false type. Between Obanua, his two wives and his mother there is no iota of friendship, even though as same family members their relationships ought to demonstrate friendship par excellence. Due to want of space, the chain of inter-relationships in Obanua's polygamous family cannot be discussed here. To substantiate the foregoing omnibus claim about the novel on friendship, however, the friendship between Ogugua, Obanua's second wife and Odafe Gwam, the Portuguese merchant and dishonest politician is hereby placed on focus. Obviously, Ogugua befriended him in search of financial succour necessitated by her husband's abject poverty worsened by his reckless drunkenness and irresponsible life, generally, especially as a family head. Gwam in turn befriended Ogugua strictly for sexual pleasure. So their friendship, not founded on mutual altruistic love, anchors on grossly misguided selfish interests. Consequently, each of both is disappointed in the other, especially Ogugua who sourced next to no financial relief from the man, but still mortgaged her dignity as a married woman. Hence, ascertaining that Gwam is no longer financially able, she retraced her steps.

Ogugua's friendship with Gwam is another demonstration of fair-weather friendship as evident in the cessation of their friendship at the very moment Gwam's financial prospects frizzled into nothingness, following the severe monetary sanction he suffered from the Great Future Party as a result of glaring dishonesty on his part. As such, their friendship teaches that once a heterogeneous friendship is immoral and illegal, being an extra-marital affair, the feminine party is mostly at the receiving end. For Ogugua, howbeit, the burden of regret is light, limited only to her missed monetary reward. It is as light as that on account of her husband's unparalleled irresponsibility or she would have been divorced after being publicly disgraced with no eye brow raised against Gwam. Hence, no friendship can be as false as an extra-marital heterogeneous one, obviously, due to its adulterous nature which offends God and humanity.

\section{Conclusion}

This study has, by means of an analytical discussion of the friendship dynamics unfolded in the reference novels, shown that friendship in quasi broad taxonomical terms is either false or true. In other words, friendship exists or does not exist between any two or more individuals. True friendship, noted in the study to be selfless and intimate, following Baconian notion of the concept, is friendship par excellence and as such anchors on St. Paul's notion of altruistic love by which it is conceptualised as a sharing of love between friends who could be homogeneous or heterogeneous, depending on their sex distribution which tallies or varies respectively. The practical implications of the foregoing are that friendship, to be perpetual, thrives on mutual desirables, especially mutual counselling, chastisement, apology and forgiveness as situations may prompt and abominates betrayal, insincerity, dishonesty and redundancy.

Consequently, the study dismisses conventional friendship types as false ones except intimate friendship which is subsumed in true friendship. The false friendship category includes but may not be limited to the following: casual, fair-weather and occasional friendships. They are so identified, because they thrive on selfish interests as demonstrated by the fair-weather type in the study, and so, likely to dovetail into immorality and illegality to possibly create room for outright gangsterism or criminality which anchors on mutual aiding and abetting by the gangsters or criminals involved who masquerade as friends. 
In the final analysis, contrary to the traditional notion of it the study, following informed cogitation, asserts that friendship is not exclusive to non-family members, and so, conceptualises it philosophically to be the fulcrum of every kind of relationship: spousal, filial, 'siblial,' kinship, professional or master-servant. The pragmatic import of the foregoing assertion is that humanity cannot do without sharing altruistic love as conceptualised by St. Paul in $1^{\text {st }}$ Corinthians 13: 4-13 the peak of which is philanthropy. This pragmatic import connects the notion of universal friendship, i.e., true friendship without companionship, but with occasional socialisation which sharply contrasts with particular friendship such as the ones analysed in this study to which companionship with frequent socialisation is integral.

\section{References}

Achebe, C. A. (1958). Things Fall Apart. Ibadan, Nigeria: Heinemann.

Achebe, C. A. (1960). No Longer at Ease. Ibadan, Nigeria: Heinemann.

Achebe, C. A. (1987). Anthills of the Savannah. Ibadan, Nigeria: Heinemann.

Francis, B. Of Friendship, Of Love. Retrieved from http://www.authorama.com/essays-of-francis-bacon-27.html

Hornby, A. S. ( $8^{\text {th }}$ Edition). Oxford Advanced Learner's Dictionary of Current English. England: Oxford University Press.

Hill, N. (1983). Think and Grow Rich. USA: Fawcett Books.

Ludlow, J. R. (1982). About Your Marriage. Hong Kong: Commonwealth Printing Ltd.

Mbukanma, J. O. (2007). Longing for God. Ibadan, Nigeria: Printmarks Ventures.

Mbukanma, J. O. (2010). Charisms of the Holy Spirit. Ibadan, Nigeria: Printmarks Ventures.

Okpewho, I. (1970). The Victims. Harlow, England: Longman Group Ltd.

Okpewho, I. (1993). Tides. Ikeja, Lagos: Longman Nigeria Plc.

Okpewho, I. (2004). Call Me by My Rightful Name. Trenton, NJ: Africa World Press.

Onyemelukwe, N. H., \& Fatuase, F. A. (2012, November). Linguistic Rhetorical Devices as Discourse Strategies in Achebe's No Longer at Ease. International Conference at University of Lagos, Nigeria.

\section{Copyrights}

Copyright for this article is retained by the author(s), with first publication rights granted to the journal.

This is an open-access article distributed under the terms and conditions of the Creative Commons Attribution license (http://creativecommons.org/licenses/by/3.0/). 